\title{
Biophysical controls on canopy transpiration in a black locust (Robinia pseudoacacia) plantation on the semi-arid Loess Plateau, China
}

\author{
Lei Jiao, ${ }^{1} \mathrm{Nan} \mathrm{Lu},{ }^{1,2 *}$ Ge Sun, ${ }^{3}$ Eric J. Ward ${ }^{4}$ and Bojie $\mathrm{Fu}^{1,2}$ \\ ${ }^{1}$ State Key Laboratory of Urban and Regional Ecology, Research Center for Eco-Environmental Sciences, Chinese Academy of Sciences, Beijing \\ 100085, China \\ 2 Joint Center for Global Change Studies, Beijing 100875, China \\ ${ }^{3}$ Eastern Forest Environmental Threat Assessment Center, USDA Forest Service, Raleigh, NC, 27606, USA \\ ${ }^{4}$ Department of Forestry and Environmental Resources, North Carolina State University, Raleigh, NC, USA
}

\begin{abstract}
In the semi-arid Loess Plateau of China, black locust (Robinia pseudoacacia) was widely planted for soil conservation and afforestation purposes during the past three decades. Investigating biophysical controls on canopy transpiration $\left(E_{\mathrm{c}}\right)$ of the plantations is essential to understanding the effects of afforestation on watershed hydrology and regional water resources. In addition to monitoring of micrometeorology and soil water content, sap flux densities $\left(F_{\mathrm{d}}\right)$ of six representative trees in a 27-year stand were continuously measured using thermal dissipation probes during the growing seasons in 2013 and 2014 . $E_{\mathrm{c}}$ was derived by multiplying stand total sapwood area $\left(A_{\mathrm{ST}}\right)$ with $F_{\mathrm{d}}$. The daily mean $E_{\mathrm{c}}$ in the growing season was 0.14 and $0.23 \mathrm{~mm} \mathrm{day}^{-1}$ in 2013 and 2014 , respectively. The responses of daily $E_{\mathrm{c}}$ to $R_{\mathrm{s}}$ and vapour pressure deficit were explained with an exponential threshold model. The variability of monthly $E_{\mathrm{c}}$ was mainly explained by leaf area index $(\mathrm{LAI})\left(R^{2}=0.92\right)$. The inter-annual variability of $E_{\mathrm{c}}$ was influenced by LAI that fluctuated dramatically during 2013 and 2014 . We found that the status of soil water content at the beginning of the growing season had large impacts on LAI and $E_{\mathrm{c}}$ during the growing season. Contrary to common beliefs that the plantation uses a large amount of water, we found that the black locust plantation had rather low transpiration rates $\left(5.3 \%\right.$ of precipitation and $4.6 \%$ of $\left.E T_{0}\right)$. This study suggests that the black locust plantation has adapted to local soil water condition by reducing transpiration, and the major water loss from the plantation was not transpiration. Copyright (C) 2015 John Wiley \& Sons, Ltd.
\end{abstract}

KEY WORDS sap flow; thermal dissipation probes; soil water budget; leaf area index; $E T_{0}$; afforestation

Received 13 May 2015; Revised 29 September 2015; Accepted 29 November 2015

\section{INTRODUCTION}

Transpiration is a physiological process that water diffuses from the plant tissue to the air through the plant stomata (Wullschleger et al., 1998). It is considered as a main process in terrestrial ecosystem water cycling (Sun et al., 2011; Schlesinger and Jasechko, 2014). Quantifying vegetation water use is important for understanding the interactions between afforestation-based ecological restoration and regional water resource (Wei and Sun, 2009).

Meteorological factors and soil water conditions exert strongly influences on canopy transpiration $\left(E_{\mathrm{c}}\right)$ (Oren et al.,

*Correspondence to: Nan Lu, Research Center for Eco-Environmental Sciences, Chinese Academy of Sciences, Beijing 100085, China; Joint Center for Global Change Studies, Beijing 100875, China.

E-mail: nanlv@rcees.ac.cn
1996; Lundblad and Lindroth, 2002; Zeppel et al., 2006; Small and McConnell, 2008; MacKay et al., 2012), and this may affect ecosystem productivity by constraining plant photosynthesis. Stomatal responses to solar radiation $\left(R_{\mathrm{s}}\right)$ and vapour pressure deficit (VPD) are two key factors in terms of the trade-off between maximizing photosynthesis and minimizing transpiration (Granier et al., 1996; Katul et al., 2010; Ghimire et al., 2014). The relationship between $E_{\mathrm{c}}$ and soil water condition was widely studied in various climatic regions (Oren et al., 1996; Oren and Pataki, 2001; Bernier et al., 2006; Manzoni et al., 2011; Chang et al., 2014a). However, inconsistent results have been reported. Some studies find that $E_{\mathrm{c}}$ was correlated with soil water content (SWC) in a polynomial or logistic fashion (Zhao and Liu, 2010; Chang et al., 2014a). The studies that based on global eddy covariance measurements suggest that SWC or precipitation is not a good predictor for seasonal evapotranspiration (ET), especially for forests because of deeper roots access to deep soil water and major controls 
on ET from canopy structure and energy availability (Sun et al., 2011; Fang et al., 2015). Impacts of soil water condition on plants transpiration are complex, especially for the plants with deep roots (Li et al., 2002; Kume et al., 2007). Some studies suggest that clearer relationships between $E_{\mathrm{c}}$ and SWC can only be developed by separating the SWC regime such as separating the dry season and the wet season in analysis (David et al., 2007; Kelley et al., 2007; Brito et al., 2015). Droughts that occur before and in the early growing season have strong effects on $E_{\mathrm{c}}$ by influencing vegetation development and growth (Noormets et al., 2008; Limousin et al., 2009; Dong et al., 2011; MacKay et al., 2012). How the SWC in pregrowing or initial growing season impacting on $E_{\mathrm{c}}$ was not clear, and there was no consistent conclusion.

For the semi-arid Loess Plateau, a series of revegetation projects have been implemented to control soil erosion since the late 1990s, during which large areas of farmlands on hillslope were converted to forest and grassland. Soil water is the main source of water for plant growth and has been regarded as one of the most limiting factor for the success of revegetation in this region. Black locust (Robinia pseudoacacia), an exotic species, was widely planted because it is a droughttolerant and fast-growing species (Wang et al., 2010b). Reforestation had positive effects on reducing soil erosion, increasing carbon sequestration and soil nutrient improvement (Feng et al., 2013; Jiao et al., 2013). A previous study showed that black locust is a species that can adapt in a prolonged water-stressed environment by reducing water loss through reducing both transpiration and leaf area (Mantovani et al., 2014). Additionally, some debates arose on the hydrological effects of the plantations in the semi-arid Loess Plateau. For example, water yield was dramatically reduced as a result of large area afforestation in this region (Sun et al., 2006). Some studies showed that the plantations excessively used soil water leading to soil desiccation, and the plantations usually degraded in early ages because of long-term water stress, which are obstacles to water cycling and sustainability of afforestation (Wang et al., 2004a; Shangguan, 2007; Chen et al., 2008). However, most of the previous studies are based on the observations of soil water changes; studies on the direct tree water use are lacking. Few existed studies only focused on the effects of climate factors on $E_{\mathrm{c}}$ (Chen et al., 2014; Zhang et al., 2015), the role of soil moisture in mediating $E_{\mathrm{c}}$ responses, and conversely, the potential effect of $E_{\mathrm{c}}$ on stand water balance was not clear, which are essential to understanding the effects of afforestation on watershed hydrology and regional water resources.

Therefore, sap flow, soil water condition and micrometeorology were simultaneously measured in a 27 - year-old black locust plantation in the Yangjuangou catchment in the central of Loess Plateau. The objectives of this study were to (1) quantify the $E_{\mathrm{c}}$ of a 27 -year-old black locust plantation in two continuous growing seasons; (2) examine the temporal dynamics of $E_{\mathrm{c}}$ at different time scales, i.e. daily, monthly and annual, and explore the mechanisms of dynamic water flux of the plantation; (3) evaluate proportion of $E_{\mathrm{c}}$ in precipitation and the potential influence of the tree transpiration on the stand water cycling in black locust plantation from the point of water balance.

\section{MATERIALS AND METHODS}

\section{Research site characteristics}

The study was carried out in the Yangjuangou catchment $\left(36^{\circ} 42^{\prime} \mathrm{N}, 109^{\circ} 31^{\prime} \mathrm{E}\right)$, located in Yan'an city of Shaanxi province, China. The area of the catchment is $2.02 \mathrm{~km}^{2}$ and the elevation ranges from 1050 to $1298 \mathrm{~m}$. The gully density is $2.74 \mathrm{~km} \mathrm{~km}^{-2}$. This region is a typical gully and hilly landscape in the Loess Plateau, which is notorious for soil erosion due to intensive vegetation destruction and cultivation. Black locust plantations were widely distributed in this catchment as a result of afforestation campaigns in the past 30 years.

The growing season is approximately from May to September for most deciduous plants. The mean annual air temperature is $9.8( \pm 0.8)^{\circ} \mathrm{C}$ and mean annual precipitation is $531.0( \pm 114.6) \mathrm{mm}$ (from 1952 to 2012 ). The average precipitation in the growing season is 422 $( \pm 103) \mathrm{mm}$, accounted for $79 \%$ of annual precipitation. Because of more precipitation than other months, the period from July to September (accounting for 58.8\% of annual precipitation) is defined as the rainy season. Therefore, we have further separated the growing season into pre-rainy season (May and June) and rainy season (July to September). The soil is derived mainly from loess, and the soil depth is approximately $50 \sim 200 \mathrm{~m}$ in the study area.

A 27-year-old black locust plantation plot was installed on a south slope in the Yangjuangou catchment (Table I). The plot was at middle slope position, and the slope floor was flat. Therefore, we assumed that there is no influence of micro topography on the plantation. The plot was selected for the reason that the plantation was planted in abandoned farmland and little disturbed by human activities. The age of the plantation was estimated based on the tree core rings sampled around the plot. The plot area is $10 \times 10 \mathrm{~m}^{2}$. The tree density was 1300 trees/ha. Understory vegetation consisted of a mosaic of patches of liana (Periploca sepium) and herb (Artemisia sacrorum). There is no shrub vegetation on the plantation floor. 
Table I. Characteristics of the study plot for sap flow measurements.

\begin{tabular}{ll}
\hline Characteristics & South plot \\
\hline Slope & $25^{\circ}$ \\
Elevation $(\mathrm{m})$ & 1179 \\
Density (trees/ha) & 1300 \\
Overstory tree species & Robinia pseudoacacia \\
Overstory cover $(\%)$ & 85 \\
Average DBH $(\mathrm{cm})$ & $9.9 \pm 4.2(2013)$ \\
& $10.8 \pm 4.3(2014)$ \\
Average height $(\mathrm{m})$ & $7.4 \pm 2.0(2013)$ \\
& $8.8 \pm 2.4(2014)$ \\
Sapwood area $\left(\mathrm{cm}^{2}\right)$ & $315.9(2013)$ \\
& $359.5(2014)$ \\
Understory species & Artemisia sacrorum and \\
& Periploca sepium \\
Understory cover $(\%)$ & 35 \\
Understory average height $(\mathrm{m})$ & 0.3 \\
Bulk density $\left(\mathrm{g} \mathrm{cm}{ }^{-2}\right) 0-40 \mathrm{~cm}$ & 1.2 \\
Soil clay $(\%) 1-100 \mathrm{~cm}$ & 3.6 \\
Soil silt $(\%) 1-100 \mathrm{~cm}$ & 66.8 \\
Soil sand $(\%) 1-100 \mathrm{~cm}$ & 29.3 \\
\hline
\end{tabular}

$\mathrm{DBH}$, diameter at breast height.

\section{Micrometeorology and soil water content measurements}

Micrometeorological variables were simultaneously monitored with sap flow measurements in the growing seasons of 2013 and 2014. Solar radiation $\left(R_{\mathrm{s}}, \mathrm{W} \mathrm{m}^{-2}\right)$ was measured by using a pyranometer (Li-200, Li-Cor, Lincoln, NE, USA), which measured 400 to $1100 \mathrm{~nm}$ wavelengths and was installed $2 \mathrm{~m}$ above ground in the open field adjacent to the plot. Air temperature $\left(T_{\mathrm{a}},{ }^{\circ} \mathrm{C}\right)$ and relative humidity ( $\mathrm{RH}, \%)$ were monitored by an HMP35C probe (Vaisala Co., Helsinki, Finland), which was installed $2 \mathrm{~m}$ above ground in the center of the plot. These data were sampled every $30 \mathrm{~s}$ and the averaged value of every $30 \mathrm{~min}$ were recorded on a CR10XTD data logger (Campbell Scientific, Logan, UT, USA). VPD $(\mathrm{kPa})$ was calculated with $T_{\mathrm{a}}$ and $\mathrm{RH}$ data (Campbell and Norman, 1998). The volumetric soil water content $\left(\mathrm{SWC}, \mathrm{m}^{3} \mathrm{~m}^{-3}\right.$ ) was measured at 10,20 , $40,60,100,120,150$ and $180 \mathrm{~cm}$ depths below the ground surface using EC-5 sensors (Decagon Devices Inc., Pullman, WA, USA). Data were recorded with a HOBO logger (H21, Onset Computer Corp., Bourne, MA, USA $)$ at $30 \mathrm{~min}$ interval. Precipitation $(P, \mathrm{~mm})$ was measured using a tipping bucket rain gauge (TE525), and wind speed and wind direction were measured using a 03001 Wind Sentry set (Campbell Scientific, Logan, UT, USA), connecting to a weather station (Dynamax Inc., Houston, USA), which was about $500 \mathrm{~m}$ from the study plot.

The grass reference ET $\left(E T_{0}, \mathrm{~mm}\right)$ that characterizes local meteorological and evaporative conditions was estimated by means of the FAO Penman-Monteith equation using the $E T_{0}$ Calculator software (http://www. fao.org/nr/water/eto.html) (Allen et al., 1998). Data of $T_{\mathrm{a}}$, $\mathrm{RH}$, wind speed and sunshine hours were the required input parameters. Previous study estimated $E T_{0}$ used the software in Loess Plateau (Zhang et al., 2013).

\section{Sap flow measurements}

$E_{\mathrm{c}}$ may be estimated by many methods such as scaling up measurements from large tree potometers (Olbrich, 1991), ventilated chambers (Denmead et al., 1993), using more complex model parameterized by leaf scale physiological traits and three-dimensional tree architecture (Kumagai et al., 2014) or sap flux density at given xylem depths (Granier, 1987; Granier et al., 1996). We used sap flow technique as it has the advantage of not limiting by landform heterogeneity (Granier, 1987; Granier et al., 1996; Kumagai et al., 2008), and thus a suitable method in the study region (Wang et al., 2010b; Du et al., 2011; Chen et al., 2014; Zhang et al., 2015).

According to the distribution frequency of diameter at breast height $(\mathrm{DBH})$ in the plot, six trees were selected for sap flow measurements. Sap flux density $\left(F_{\mathrm{d}}\right)$ was measured using the Granier-type thermal dissipation probes. A thermal dissipation probes sensor consists of a pair of probes with $10 \mathrm{~mm}$ long and $1.2 \mathrm{~mm}$ in diameter, a heated needle above and a reference needle below. The upper probe includes a heater, which was supplied with $0.15 \mathrm{~W}$ constant power. A copper-constantan thermocouple junction was enclosed in each probe. The thermocouple junction was located at $5 \mathrm{~mm}$ depth in the probe. After removal of the bark outside the sapwood, the sensor was inserted into the sapwood area vertically $40 \mathrm{~mm}$ apart at breast height. The temperature difference between the upper heated probe and the lower reference probe was measured every $30 \mathrm{~s}$ and recorded the averaged value every $30 \mathrm{~min}$ on a CR10XTD data logger (Campbell Scientific Inc., Logan, UT, USA). The sensors were installed in the north orientation of the stem. To prevent rainfall or water running down from the stem and touching the sensors, plastic putty was installed around the probes. To prevent the solar heating, reflective bubbles were wrapped the tree where the measurement was taken.

$F_{\mathrm{d}}\left(\mathrm{g} \mathrm{m}^{-2} \mathrm{~s}^{-1}\right)$ was calculated with the empirical model based on temperature difference between the two probes according to Granier (1987) as following:

$$
F_{d}=119\left(\frac{\Delta T_{\mathrm{m}}-\Delta T}{\Delta T}\right)^{1.231}
$$

where $\Delta T$ is the temperature difference between the upper heated probe and the lower reference probe and 
$\Delta T_{\mathrm{m}}$ is the maximum value of $\Delta T$ when $F_{\mathrm{d}}$ is zero at nighttime (Lu et al., 2004).

If the sapwood thickness $\left(T_{\mathrm{s}}, \mathrm{cm}\right)$ was smaller than probe length, $F_{\mathrm{d}}$ should be underestimated because of a portion of the probe was inserted into the nonconductive xylem. Calibration was conducted according to the following method (Clearwater et al., 1999):

$$
\Delta T_{\mathrm{sw}}=\frac{\Delta T-b \Delta T_{\mathrm{m}}}{a}
$$

where $a$ is the proportion of probe in sapwood, $b$ is the proportion of probe in inactive xylem $(b=1-a)$ and $\Delta T_{\mathrm{sw}}$ is the temperature difference in sapwood. In formula $3, \Delta T$ was replaced by $\Delta T_{\mathrm{sw}}$.

$T_{\mathrm{s}}$ of sampled trees was determined by regressions of bark thickness $\left(T_{\mathrm{b}}, \mathrm{cm}\right)$ and sapwood area $\left(A_{\mathrm{s}}, \mathrm{cm}^{2}\right)$ data on DBH (Zhang et al., 2015). $T_{\mathrm{b}}$ of sampled tress was calculated with a linear regression between $T_{\mathrm{b}}$ and DBH. $A_{\mathrm{s}}$ of sampled trees was calculated by a power regression between $A_{\mathrm{s}}$ and DBH (Vertessy et al., 1995). We found similar relationships between $T_{\mathrm{b}}$ and $\mathrm{DBH}$ and $A_{\mathrm{s}}$ and $\mathrm{DBH}$ in this study. The regression formulas were $T_{\mathrm{b}}=0.30+0.05 \times \mathrm{DBH} \quad\left(R^{2}=0.74, n=22\right) \quad$ and $A_{\mathrm{s}}=0.61 \times \mathrm{DBH}^{1.55}\left(R^{2}=0.94, n=22\right)$.

$T_{\mathrm{b}}$ and $A_{\mathrm{s}}$ were estimated based on tree core samples from 22 trees adjacent to the study plot. Samples were taken at DBH using an increment core borer. The tree DBH was measured at the beginning of each growing season in 2013 and 2014. $T_{\mathrm{b}}$ and $A_{\mathrm{s}}$ of all trees in the study plot were estimated based on the regression models. The total sapwood area of the stand $\left(A_{\mathrm{ST}}\right)$ was $315.85 \mathrm{~cm}^{2}$ in 2013 and $359.48 \mathrm{~cm}^{2}$ in 2014 , respectively.

\section{Estimation of $E_{c}$ from sap flow measurements}

$E_{\mathrm{c}}\left(\mathrm{mm} \mathrm{day}^{-1}\right)$ was calculated with the following formula:

$$
E_{c}=\frac{J_{\mathrm{s}} A_{\mathrm{ST}}}{A_{\mathrm{G}}}
$$

where $\mathrm{J}_{\mathrm{s}}\left(\mathrm{kg} \mathrm{m}^{-2}\right.$ day $\left.^{-1}\right)$ is stand sapflux density, $A_{\mathrm{ST}}$ is total sapwood area in study plot and $A_{\mathrm{G}}$ is the ground area.

$J_{\mathrm{s}}$ is calculated with the following formula:

$$
J_{\mathrm{s}}=\frac{\sum F_{\mathrm{di}} A_{\mathrm{si}}}{A_{\mathrm{ST}}}
$$

where $F_{\mathrm{di}}$ is the mean $F_{\mathrm{d}}$ of the $i$ th DBH class and $A_{\mathrm{si}}$ is the total sapwood area of $i$ th DBH class.

$A_{\mathrm{ST}}$ is calculated with the following formula:

$$
A_{\mathrm{ST}}=\sum A_{\mathrm{si}}
$$

where $A_{\mathrm{si}}$ is the total sapwood of trees in ith DBH class.

\section{Estimation of $E_{c}$ from leaf gas exchange measurements}

To verify the estimates of $E_{\mathrm{c}}$ from sap flow methods, the gas exchange of an individual leaf was measured and scaled to $E_{\mathrm{c}}$. The leaf transpiration rate $\left(E_{1}\right)$ was measured with a portable infrared gas analyser system with a $2 \times 3 \mathrm{~cm}^{2}$ chamber (LI-6400, Li-Cor Inc., Lincoln, NE, USA) on three sunny days: 29 June, 30 August in 2013 and 14 July in 2014. Three sampled trees were selected and three leaves were measured in each tree. The sampled leaves were all at the middle position of the canopy in the south orientation, on the assumption that the leaf gas exchange traits at the measured position approximated the whole canopy. Measurements were conducted every hour from 6:00 in the morning to 18:00 in the afternoon.

$\mathrm{E}_{\mathrm{c}-1}\left(\mathrm{~mm} \mathrm{~h}^{-1}\right)$ was computed as a product of transpiration rate of individual leaves and leaf area:

$$
E_{\mathrm{c}-1}=L A I \times A_{\mathrm{G}} \times \sum E_{\mathrm{li}}
$$

where LAI is leaf area index at the measurement period, $A_{\mathrm{G}}$ is the ground area of stand and $E_{\mathrm{li}}$ is leaf transpiration rate at $i$ hour $\left(\mathrm{kg} \mathrm{m}^{-2}\right.$ ground area $\left.\mathrm{h}^{-1}\right)$.

\section{Overstory leaf area index}

Overstory leaf area index was measured using a plant canopy analyser (LAI-2000, Li-Cor, Lincoln, NE, USA) twice a month at 10 or 15 days intervals from June to September in 2013 and from May to September in 2014. The measurement was taken at $1.3 \mathrm{~m}$ height above ground (not including understory layer). on cloudy days or at dusk. Each measurement represents the average of three samples on each date.

\section{Stand water balance}

The water balance for a stand and watershed during a longterm period (monthly or annual) can be described as

$$
P=E T+Q+\Delta S
$$

where, $P, E T, Q$ and $\Delta S$ are precipitation, evapotranspiration, runoff and change of soil water storage (Sun et al., 2006). Monthly $\Delta S(\mathrm{~mm})$ in $0-180 \mathrm{~cm}$ profile was calculated according to initial and final SWC of each growing season (Wang et al., 2012). ET and its components can be expressed as

$$
E T=E_{\mathrm{i}}+E_{\mathrm{c}}+E_{\mathrm{s}}
$$

where $E_{\mathrm{i}}$ is canopy interception, $E_{\mathrm{c}}$ is canopy transpiration and $E_{\mathrm{s}}$ is soil evaporation (Sun et al., 2014).

$E_{\mathrm{i}}$ was approximately estimated by the Gash analytical model (Gash, 1979). The model can be expressed as 
$E_{\mathrm{i}}=n\left(1-\mathrm{p}-\mathrm{p}_{\mathrm{t}}\right) \mathrm{P}_{\mathrm{G}}^{\prime}+\frac{\bar{E}}{R} \sum_{j=1}^{n}\left(P_{\mathrm{Gj}}-P_{\mathrm{G}}^{\prime}\right)+\left(1-p-p_{\mathrm{t}}\right) \sum_{j=1}^{m} P_{\mathrm{Gj}}+q S_{\mathrm{t}}+p_{\mathrm{t}} \sum_{j=1}^{m+n-q} P_{\mathrm{Gj}}$

where $n$ is the numbers of the rainfalls that saturate the canopy; $m$ is the numbers of rainfalls that would not saturate the canopy; $q$ is the numbers of rainfalls that saturate the trunk; $p$ is free throughfall coefficient; $p_{\mathrm{t}}$ is proportion of rain diverted to stemflow; $\bar{E}$ mean rate of evaporation from a saturated canopy $\left(\mathrm{mm} \mathrm{h}^{-1}\right) ; \bar{R}$ is mean rainfall rate $\left(\mathrm{mm} \mathrm{h}^{-1}\right) ; S_{\mathrm{t}}$ is trunk storage capacity $(\mathrm{mm})$; $P^{\prime}{ }_{\mathrm{G}}$ is amount of rainfall to saturate the canopy $(\mathrm{mm})$; and $P_{\mathrm{Gj}}$ is gross rainfall on the canopy $(\mathrm{mm})$.

The parameter in the aforementioned model determined by Wang et al. (2013) was used in this study. Their study site was located in the Yangou catchment, nearly $30 \mathrm{~km}$ distance from our study site, under similar climatic condition. Additionally, the characteristics of their experimental plot were similar to those in this study, with 27 years old, $6.9 \mathrm{~m}$ mean height, $10.2 \mathrm{~cm}$ mean DBH and 900 trees/ha. During the growing seasons in 2013 and 2014, 53 and 55 individual rainfalls were recorded, respectively.

In this study, only the components of $P, \Delta S, E_{\mathrm{c}}, E_{\mathrm{i}}$ and $E T_{0}$ were quantified. We aimed to get a basic understanding of the role of trees in the stand water cycling but not to close the water balance.

\section{Statistical analyses}

$T$-test was performed to examine whether the micrometeorological factors were different between the two growing seasons.

To analyse the responses of $E_{\mathrm{c}}$ to VPD and $R_{\mathrm{s}}$ at daily scale, an exponential threshold model was used (Ewers et al., 2002):

$$
E_{\mathrm{c}}=a\left(1-e^{-b x}\right)
$$

where $\mathrm{a}$ and $\mathrm{b}$ are fitting parameters, $E_{\mathrm{c}}$ is daily canopy transpiration $\left(\mathrm{mmday}^{-1}\right)$ and $x$ is corresponding meteorological variables.

Stepwise regression analysis was used to examine the main factors controlling $E_{\mathrm{c}}$ at monthly scales (the independent variables included $E T_{0}, R_{\mathrm{s}}, V P D, R H, T_{\mathrm{a}}$, $S W C$ and $L A I$ ), respectively. A combination of forward and backward selections was used in the regression. All statistical analyses were performed with SPSS 16.0 software package (SPSS Inc., Chicago, IL, USA).

\section{RESULTS}

\section{Micrometeorology}

Mean daily $R_{\mathrm{S}}$ was not significantly different between the two growing seasons $(p>0.05)$ and showed similar seasonal trends (Figure 1). Mean $R_{\mathrm{s}}$ in the entire growing season was $160 \mathrm{~W} \mathrm{~m}^{-2}$ in 2013 and $179 \mathrm{~W} \mathrm{~m}^{-2}$ in 2014 , respectively. Daily $R_{\mathrm{s}}$ showed a declining trend from May to September. Maximum monthly $R_{\mathrm{s}}$ was recorded in May and the minimum value in September. Daily daytime VPD in the growing season of 2013 was significantly higher than that in 2014 ( $p<0.01$ ), being $1.07 \mathrm{kPa}$ in 2013 and $0.84 \mathrm{kPa}$ in 2014 , respectively. Maximum monthly daytime VPD was observed in May in 2013 and in June in 2014. Mean daily $T_{\mathrm{a}}$ between the two growing season was similar $(p>0.05)$. The highest daily $T_{\mathrm{a}}$ was recorded at the end of June in 2013 and at the end of July in 2014. Decrease of $R_{\mathrm{s}}, \mathrm{VPD}$ and $T_{\mathrm{a}}$ in the rainy season was probably related to increasing cloudy and rainy days in this time period.

The growing season $P$ was $624 \mathrm{~mm}$ in 2013 and $444 \mathrm{~mm}$ in 2014, indicating that 2013 was a wet year and 2014 was a normal year in compared with the long-term mean. A total of $413 \mathrm{~mm}$ of rainfall occurred in July 2013 from

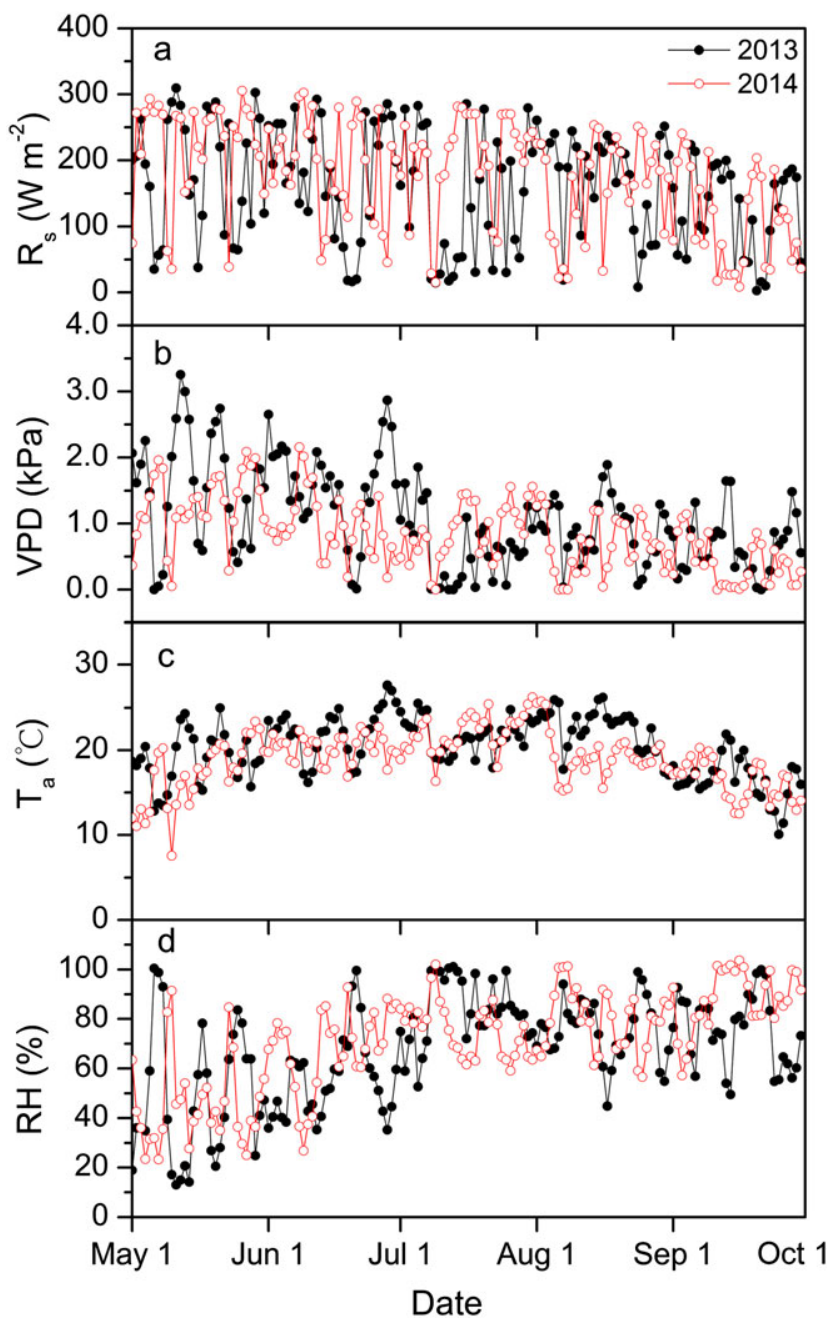

Figure 1. Variations in (a) daily solar radiation $\left(R_{\mathrm{S}}\right)$, (b) mean daytime vapor pressure deficit (VPD), (c) mean air temperature $\left(T_{\mathrm{a}}\right)$ and (d) mean relative humidity $(\mathrm{RH})$ of the study plot during the growing seasons in 2013 and 2014. 
several extreme rainfall events. Overall, the mean SWC of $0-180 \mathrm{~cm}$ in 2013 was higher than that in $2014(p<0.01)$. However, it was noted that SWC at the beginning of the growing season in 2014 was higher than that in 2013 $(p<0.01)$, with a mean value of $0.14 \mathrm{~m}^{3} \mathrm{~m}^{-3}$ and $0.09 \mathrm{~m}^{3} \mathrm{~m}^{-3}$, respectively (Figure 2). The SWC profile (10 to $180 \mathrm{~cm}$ depth) varied dramatically over time in the two growing seasons as a result of periodical rainfalls and water loss through ET and soil moisture redistribution within the soils (Figure 3).

\section{Temporal dynamics of $E_{c}$ and the impacting factors}

The daily $E_{\mathrm{c}}$ ranged from 0.03 to $0.23 \mathrm{~mm} \mathrm{day}^{-1}$ in 2013 and from 0.04 to $0.45 \mathrm{mmday}^{-1}$ in 2014 . The $E_{\mathrm{c}}$ rates peaked in pre-rainy season, in 29 May 2013 and in 26 June 2014. The dynamic patterns of daily $E_{\mathrm{c}}$ were similar in both growing seasons in 2013 and 2014 (Figure 2). At the monthly scale, the maximum $E_{\mathrm{c}}$ occurred in May in 2013 $\left(5.4 \mathrm{~mm} \mathrm{month}^{-1}\right)$ and June in $2014\left(9.0 \mathrm{~mm} \mathrm{month}^{-1}\right)$. Monthly $E_{\mathrm{c}}$ tended to decrease from July to September (Figure 2). Lowest monthly $E_{\mathrm{c}}$ was 2.55 and $4.25 \mathrm{~mm} \mathrm{month}^{-1}$ in September 2013 and 2014, respectively (Table II). At the annual scale, the mean daily $E_{\mathrm{c}}$ of the growing season was $0.14 \mathrm{mmday}^{-1}$ in 2013 and $0.23 \mathrm{~mm} \mathrm{day}^{-1}$ in 2014. Overall, cumulative $E_{\mathrm{c}}$ in the plantation during the growing season was $21 \mathrm{~mm}$ in 2013 and $36 \mathrm{~mm}$ in 2014.

Daily $E_{\mathrm{c}}$ increased sharply with $R_{\mathrm{s}}$ and VPD and tended to level off at higher values of $R_{\mathrm{S}}$ and VPD in both growing seasons. Including $R_{\mathrm{S}}$ and VPD as the independent variables, the exponential threshold models for daily $E_{\mathrm{c}}$ were as follows (Figure 4):

2013:

$$
\begin{aligned}
E_{\mathrm{c}}=0.18 \times & \left(1-\mathrm{e}^{-0.01 \times R_{s}}\right), R^{2}=0.60, P<0.001 \\
E_{\mathrm{c}}= & 0.19 \times\left(1-\mathrm{e}^{-1.73 \times V P D}\right), R^{2}=0.58, \\
& P<0.001
\end{aligned}
$$

2014:

$$
\begin{gathered}
E_{\mathrm{c}}=0.29 \times\left(1-\mathrm{e}^{-0.01 \times R_{\mathrm{s}}}\right), R^{2}=0.45, P<0.001 \\
E_{\mathrm{c}}=0.27 \times\left(1-\mathrm{e}^{-4.01 \times V P D}\right), R^{2}=0.40, P \\
\quad<0.001
\end{gathered}
$$

In both growing seasons, $R_{\mathrm{s}}$ explained more variability of daily $E_{\mathrm{c}}$ than $V P D$.

Overall, LAI in 2014 was much higher than that in 2013 (Figure 5), although the seasonal trends were similar. Stepwise regression analysis of monthly $E_{\mathrm{c}}$ resulted in a

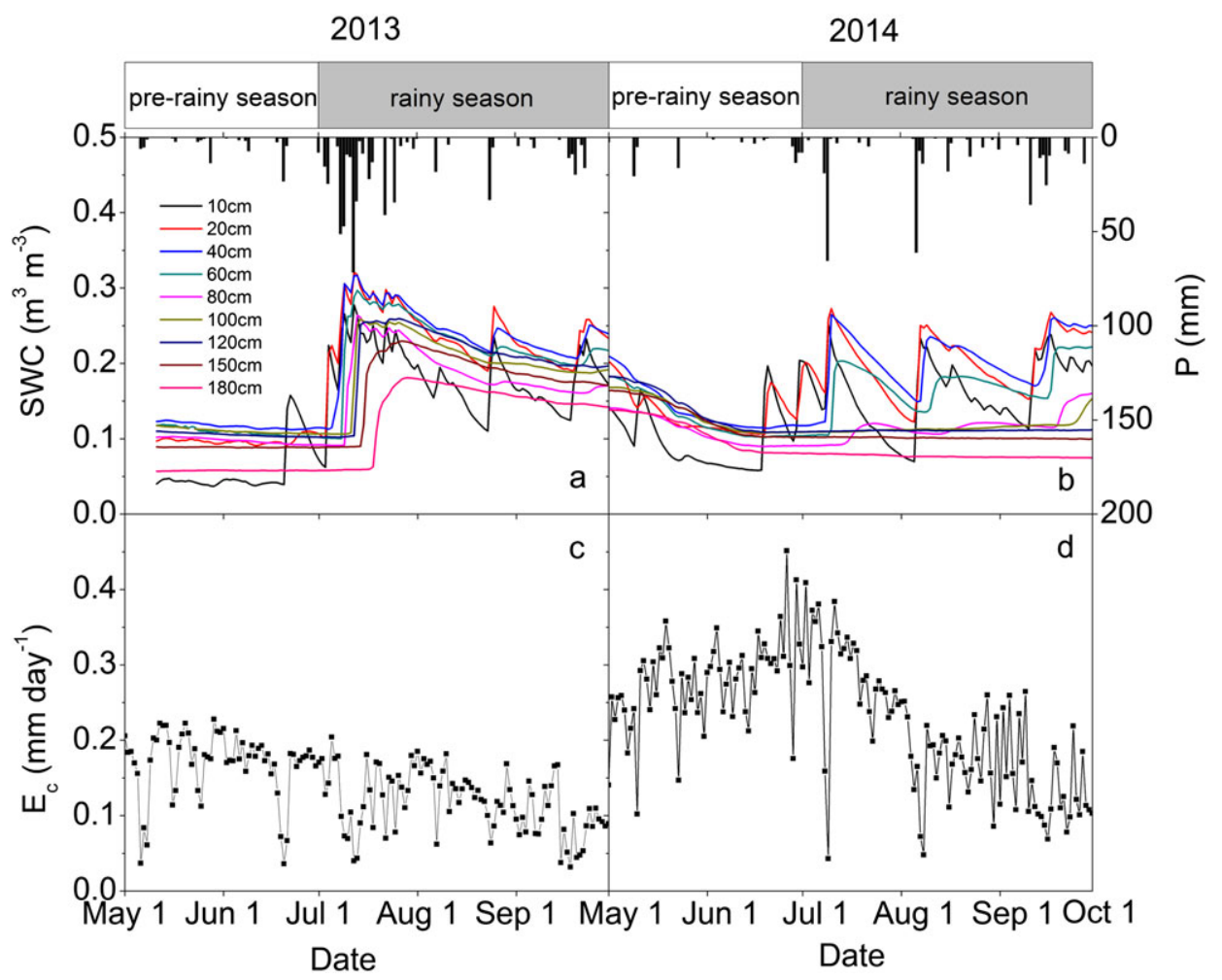

Figure 2. Daily canopy transpiration $\left(E_{\mathrm{c}}\right)$, precipitation $(P)$ and volumetric soil water content (SWC) in $0-180 \mathrm{~cm}$ depth in study plot during 2013 and 2014 growing seasons. The growing season was separated into pre-rainy season and rainy season. 


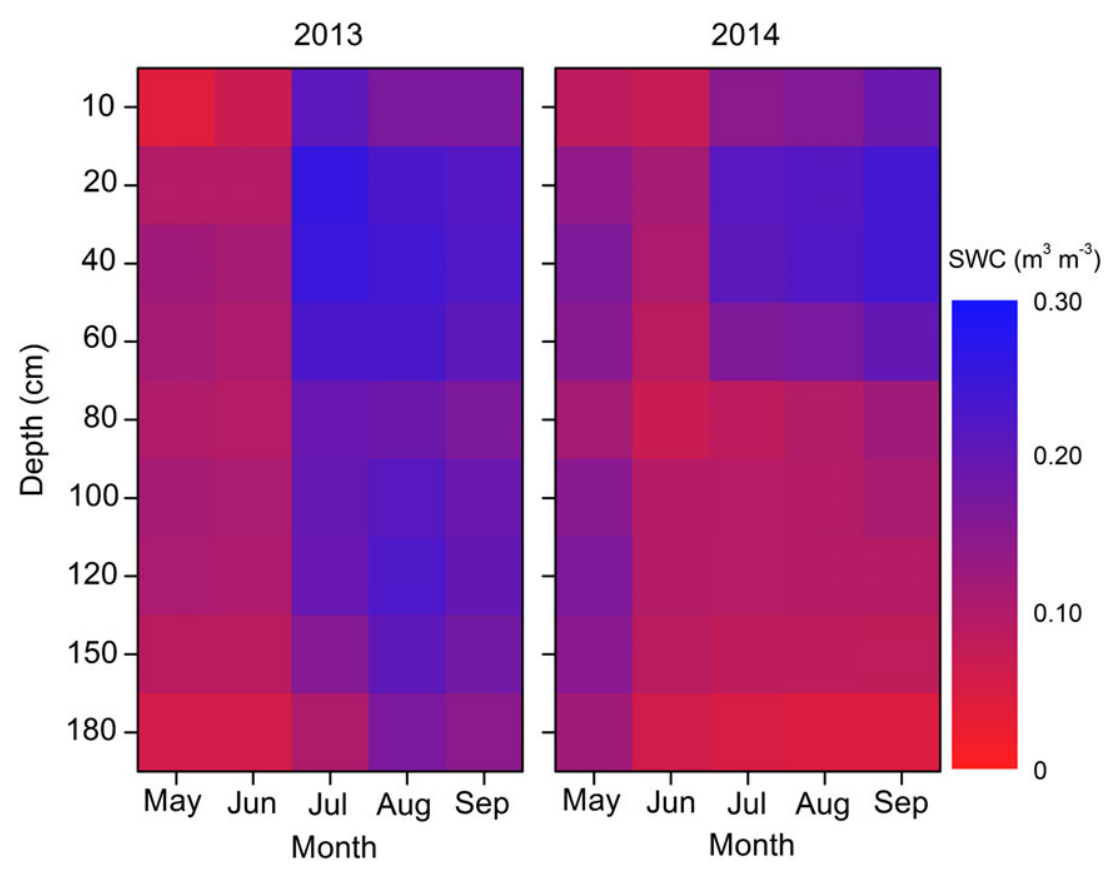

Figure 3. Vertical distribution and monthly variations in soil water content (SWC) in the $0-180 \mathrm{~cm}$ profile during growing seasons in 2013 and 2014.

Table II. Monthly canopy transpiration $\left(E_{\mathrm{c}}\right)$, change in soil water storage in the $0-180$ profile $(\triangle S)$, precipitation $(P), E_{\mathrm{c}} / P$ ratio, $E_{\mathrm{c}} / E T_{0}$ ratio during May to September in 2013 and 2014.

\begin{tabular}{|c|c|c|c|c|c|c|c|c|}
\hline Month & $E_{\mathrm{c}}(\mathrm{mm})$ & $\Delta S^{\mathrm{a}}(\mathrm{mm})$ & $E_{\mathrm{i}}(\mathrm{mm})$ & $P(\mathrm{~mm})$ & $E_{\mathrm{c}} / P(\%)$ & $E_{\mathrm{i}} / P(\%)$ & $E T_{0}(\mathrm{~mm})$ & $E_{\mathrm{c}} / E T_{0}(\%)$ \\
\hline May & $5.4\left(4.1^{\mathrm{c}}\right)$ & $-4.3^{\mathrm{b}}$ & & 33.8 & 15.6 & & 137.7 & 3.8 \\
\hline Jun & 5.0 & 4.7 & & 42.2 & 11.8 & & 148.8 & 3.3 \\
\hline Jul & 4.0 & 230.9 & & 412.5 & 1.0 & & 128.8 & 3.1 \\
\hline Aug & 4.1 & -60.5 & & 62.2 & 6.6 & & 127.8 & 3.2 \\
\hline Sep & 2.8 & -8.3 & & 73.4 & 3.5 & & 80.0 & 3.2 \\
\hline Growing season & 21.3 & 162.5 & 65.7 & 624.1 & 3.4 & 10.5 & 623.1 & 3.4 \\
\hline May & 7.9 & -95.8 & & 44.7 & 17.9 & & 132.2 & 6.1 \\
\hline Jun & 9.0 & 11.0 & & 36.6 & 24.7 & & 139.3 & 6.3 \\
\hline Jul & 8.9 & -1.2 & & 106.5 & 8.4 & & 140.7 & 6.5 \\
\hline Aug & 5.5 & 25.8 & & 122.7 & 4.4 & & 114.5 & 4.7 \\
\hline Sep & 4.3 & 56.1 & & 133.9 & 2.7 & & 77.78 & 4.7 \\
\hline Growing season & 35.6 & -4.1 & 50.9 & 444.4 & 8.0 & 11.5 & 604.48 & 5.9 \\
\hline
\end{tabular}

\footnotetext{
${ }^{\text {a }}$ Negative $\Delta S$ value represents soil water loss and positive $\Delta S$ value represents soil water recharge.

${ }^{\mathrm{b}}$ Data for 11 to 31 May.

${ }^{\mathrm{c}}$ Data for 11 to 31 May.
}

model with LAI as the only variable determining $E_{\mathrm{c}}$. The regression was (Figure 6)

$$
E_{c}=-4.4+4.5 \times L A I, R^{2}=0.92
$$

During the two continuous growing seasons, LAI was positive correlated with monthly $E_{\mathrm{c}}$. Most of the variability of monthly $E_{\mathrm{c}}$ was explained by LAI.

\section{$E_{c}$ and the stand water budget}

$E_{\mathrm{c}}$ of the black locust plantation was a small proportion in the stand water budget. Monthly $E_{\mathrm{c}} / P$ ratio was rather low in both growing seasons. However, monthly $E_{\mathrm{c}} / P$ ratio in pre- rainy season was significantly higher than that in rainy season. The maximum ratio was $16 \%$ in May 2013 and $25 \%$ in June 2014. Total $E_{\mathrm{i}}$ in growing season was $65.7 \mathrm{~mm}$ in 2013 and $50.9 \mathrm{~mm}$ in 2014, accounting for $10.5 \%$ and $11.5 \%$ of $P$, respectively (Table II). $\Delta S$ varied dramatically by month because of the dynamics of soil water recharge from rainfall and water loss from $E_{\mathrm{c}}$ and $E_{\mathrm{s}}$. It was noted that $E_{\mathrm{c}}$ was similar to the change in $\Delta S$ during the period without rainfall from 11 May to 31 May in 2013. $E_{\mathrm{c}} / E T_{0}$ ratios in different months were similar during the growing season in 2013 , ranging from $3.10 \%$ to $3.90 \%$. However, the ratio ranged from $3.78 \%$ to $6.48 \%$ in 2014 . 

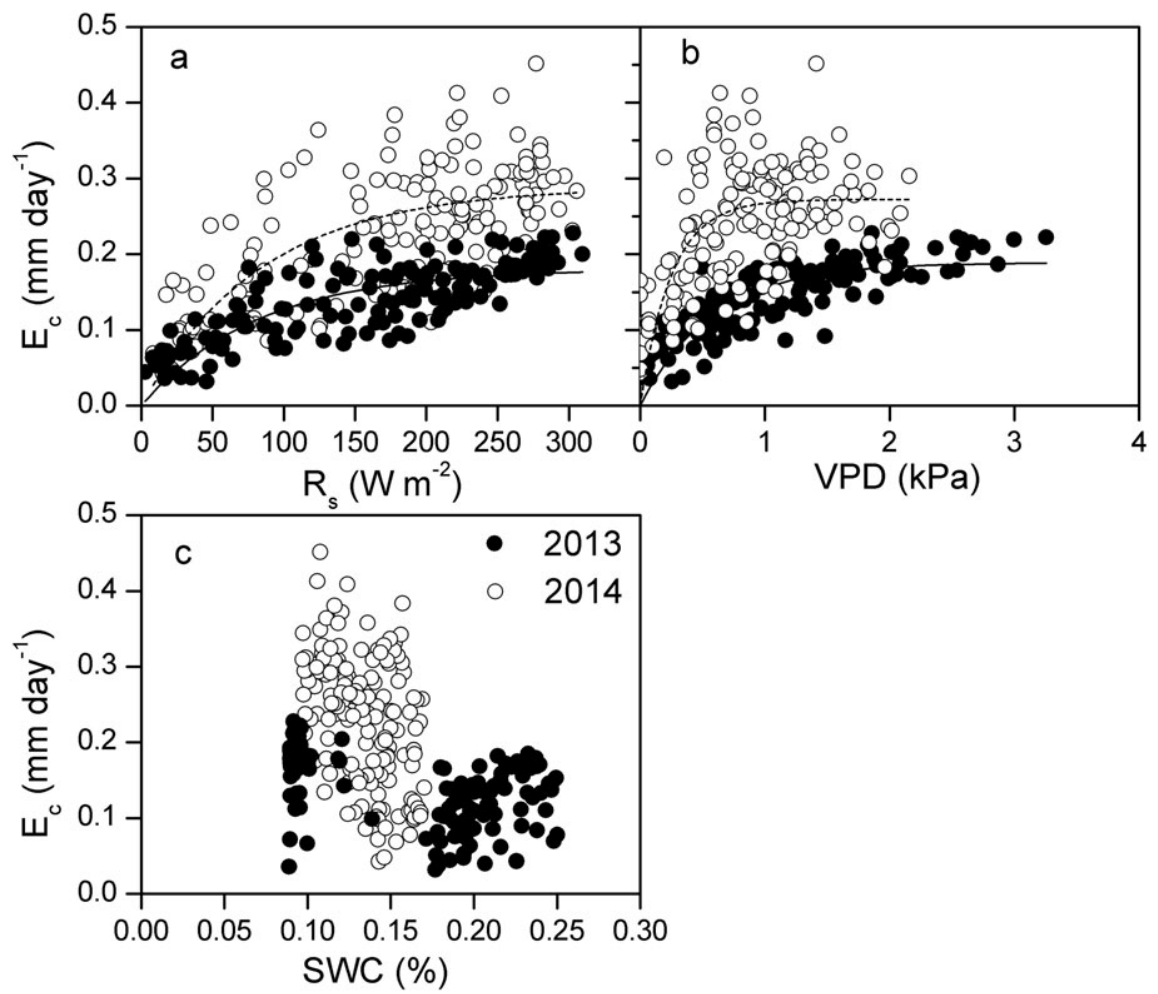

Figure 4. Relationships between daily $E_{\mathrm{c}}$ and (a) daily solar radiation $\left(R_{\mathrm{s}}\right)$, (b) daily daytime vapor pressure deficit (VPD), (c) daily soil water content (SWC) during growing seasons in 2013 and 2014.

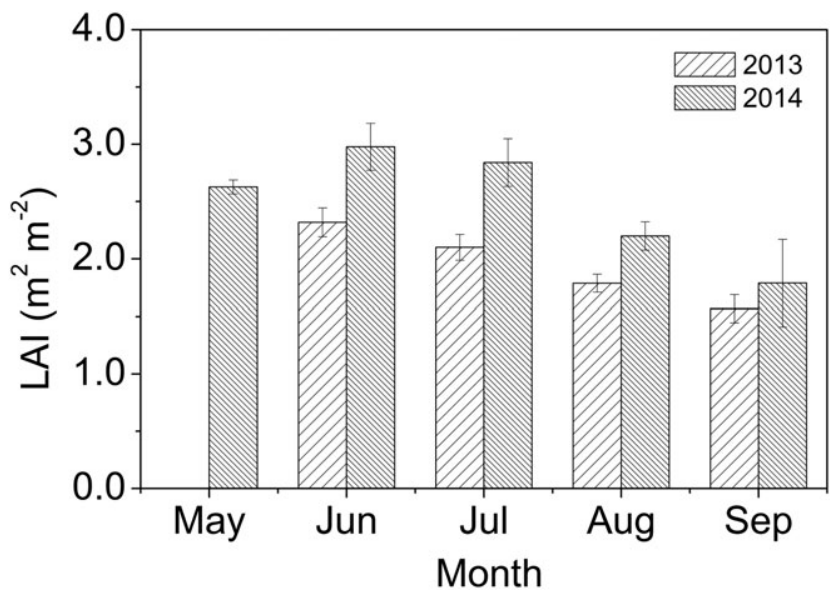

Figure 5. Variation in monthly leaf area index (LAI) of the black locust plantation during growing seasons in 2013 and 2014. Error bars represent standard deviations.

\section{DISCUSSION}

Comparing $E_{c}$ estimated by the thermal dissipation probes method and porometers

To test the magnitude of $E_{\mathrm{c}}$ estimated by sap flow method in this study, we conducted gas exchange measurements with a porometer on individual leaves. There are many uncertainties in scaling such measurements to the canopy scale (Jarvis and Mcnaughton, 1986), as both leaf

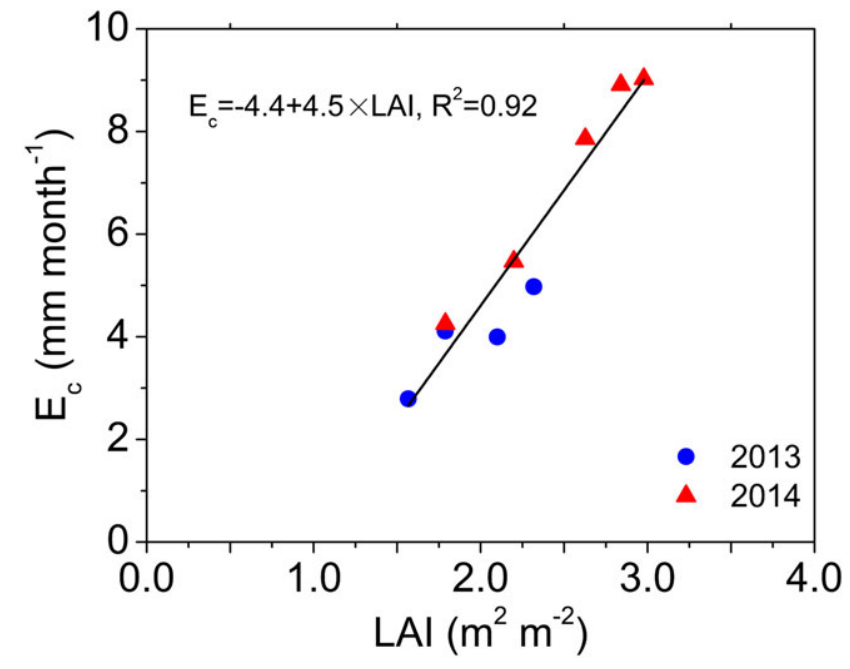

Figure 6. Relation between monthly leaf area index(LAI) and $E_{\mathrm{c}}$ in two growing seasons.

characteristics and environmental conditions, such as light and temperature, have high spatial variability within a canopy (Kupper et al., 2006). The leaf $E_{\mathrm{c}}$ value could be overestimated as the measurements were taken only on the leaves facing south (Figure 7). On the other hand, $E_{\mathrm{c}}$ values could be underestimated because of radial variations in $F_{\mathrm{d}}$, which introduced 33 44\% error in estimating $E_{\mathrm{c}}$ in black locust plantation (Kume et al., 2012). Although the leaf $E_{\mathrm{c}}$ 


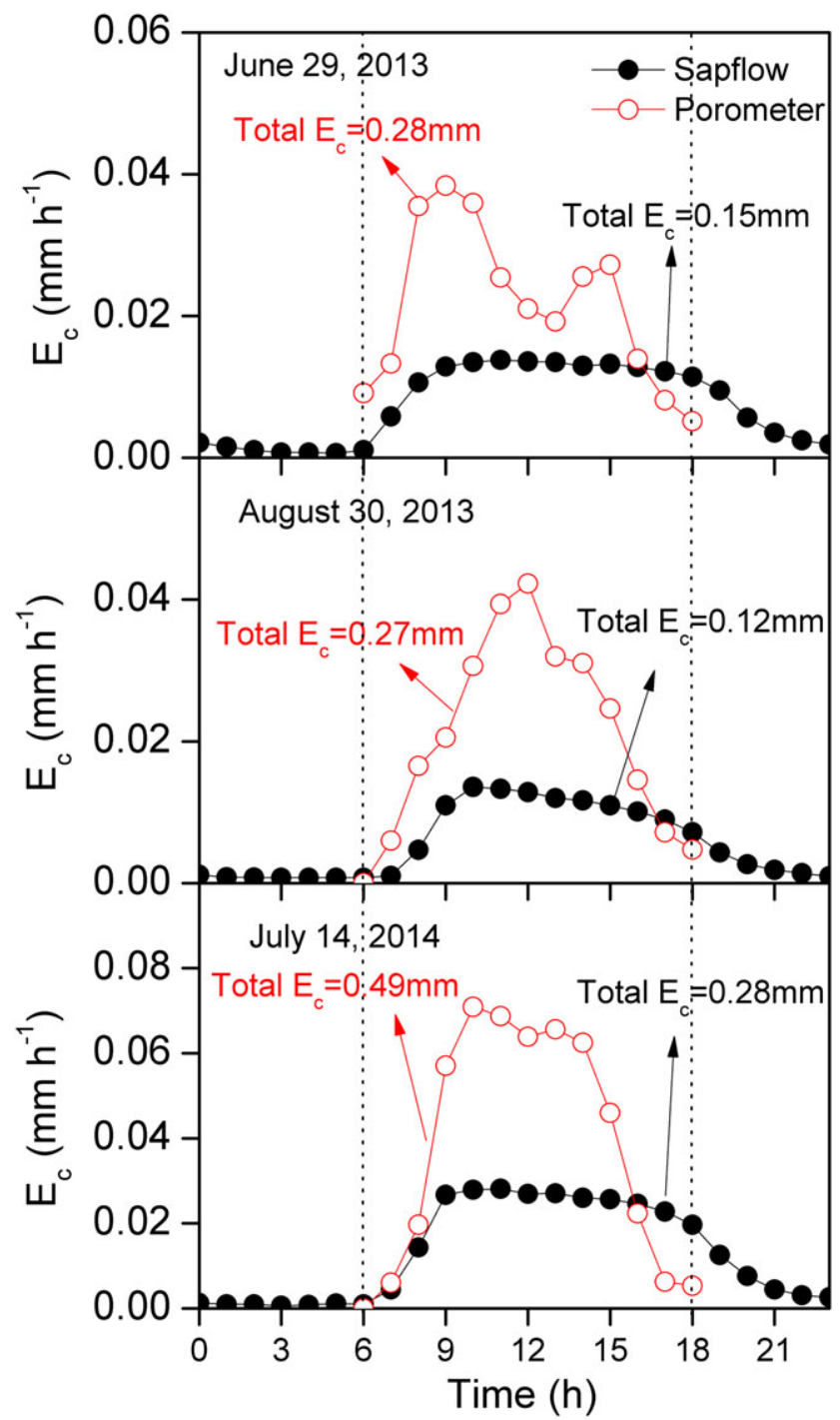

Figure 7. A comparison of $E_{\mathrm{c}}$ estimated by the sapflow method and by leaf gas exchange method. Cumulative $E_{\mathrm{c}}$ was also showed.

and sapflow measurements approximately represented canopy $E_{\mathrm{c}}$ because of methodological limitations, they verified the general magnitude of canopy $E_{\mathrm{c}}$.

Low $E_{\mathrm{c}}$

The $E_{\mathrm{c}}$ rates in our study were rather low compared with the means of temperate forests (Fang et al., 2015), but the values were comparable with the findings from other studies in the semi-arid area of the Loess Plateau (Table III). There are at least four possible reasons for the low $E_{\mathrm{c}}$. Firstly, the relatively lower $E_{\mathrm{c}}$ value in our study may be due to the lower tree density and $A_{\mathrm{ST}}$ as the values of $F_{\mathrm{d}}$ were in similar ranges compared with other plantations, including black locust and other studies (e.g. oak and eucalyptus) (Wang et al., 2010b). The daily mean and peak $J_{\mathrm{s}}$ in each month were showed in Table IV. Secondly, plants may have undergone structural and developmental changes to adapt to longterm water stress in the study area (Shan et al., 2003; Wang et al., 2004b; Wang et al., 2010b). A study showed that black locust can survive under prolonged water stress by reducing water loss through reducing both transpiration and leaf area (Mantovani et al., 2014). In this study, reduction in LAI for 2013 could be related to drought at beginning of growing season. Larger LAI for 2014 was due to higher SWC at beginning of growing season. Thirdly, as found in some other studies, these trees may have strictly regulated their transpiration in response to short-term water stress during periods of high VPD and low soil moisture (Chen et al., 2014). In this study, the trees transpired more water in June compared with other months and tapped water from deeper soil layer under higher VPD and lower SWC during same period. Furthermore, determination of total $F_{\mathrm{d}}$ in the sapwood by a single point measurement could be a large error for estimating tree and canopy transpiration due to radial variation in $F_{\mathrm{d}}$ in the sapwood (Nadezhdina et al., 2002; Ford et al., 2004). On one hand, radial variation in $F_{\mathrm{d}}$ in the trunk was widely observed in various forest tree, which were different among species (Delzon et al., 2004; Cohen et al., 2007; Kumagai et al., 2007; Chang et al., 2014a). For the black locust in Loess Plateau, $F_{\mathrm{d}}$ decreased from the outmost xylem to the inner xylem, and the $F_{\mathrm{d}}$ at the depth of $>10 \mathrm{~mm}$ was almost zero, which was conducted in August because of ideal environmental conditions (i.e. sufficient soil water, appreciable diurnal variations in radiation, temperature and humidity) at that time (Kume et al., 2012). Kume et al. (2012) also suggested that omitting radial variation in $F_{\mathrm{d}}$ could be $33 \sim 44 \%$ of the error for estimating $E_{\mathrm{c}}$ of the black locust plantations. On the other hand, the radial profile of $F_{\mathrm{d}}$ changed under varied soil water, VPD and radiation conditions, which correlated to changes of hydraulic conductivity in the trunk ( $\mathrm{Lu}$ et al., 2000; Nadezhdina et al., 2002; Delzon et al., 2004; Ford et al., 2004; del Campo et al., 2014). Taken together, the measurement at a point in $5 \mathrm{~mm}$ depth in the probe probably introduced a potential error for estimating total $F_{\mathrm{d}}$ in whole sapwood and upscaling $E_{\mathrm{c}}$. Finally, circumferential variations in $F_{\mathrm{d}}$ in the stems from measurement of individual trees (Clearwater et al., 1999; Lu et al., 2000; Lu et al., 2004; Kume et al., 2012; Chang et al., 2014a) and errors from the scaling process (i.e. classification in DBH distribution) can be sources of errors for $E_{\mathrm{c}}$ estimates. Sap flow measurement was conducted only in the north orientation in this study. Data was not available to indicate circumferential variations in $F_{\mathrm{d}}$ and to access the potential error for estimating $E_{\mathrm{c}}$. However, Kume et al. (2012) suggested that omitting circumferential variation in $F_{\mathrm{d}}$ affected $E_{\mathrm{c}}$ estimate by $16 \sim 21 \%$ errors in the black locust plantation in Loess Plateau. 
BIOPHYSICAL CONTROLS ON TRANSPIRATION IN A BLACK LOCUST PLANTATION

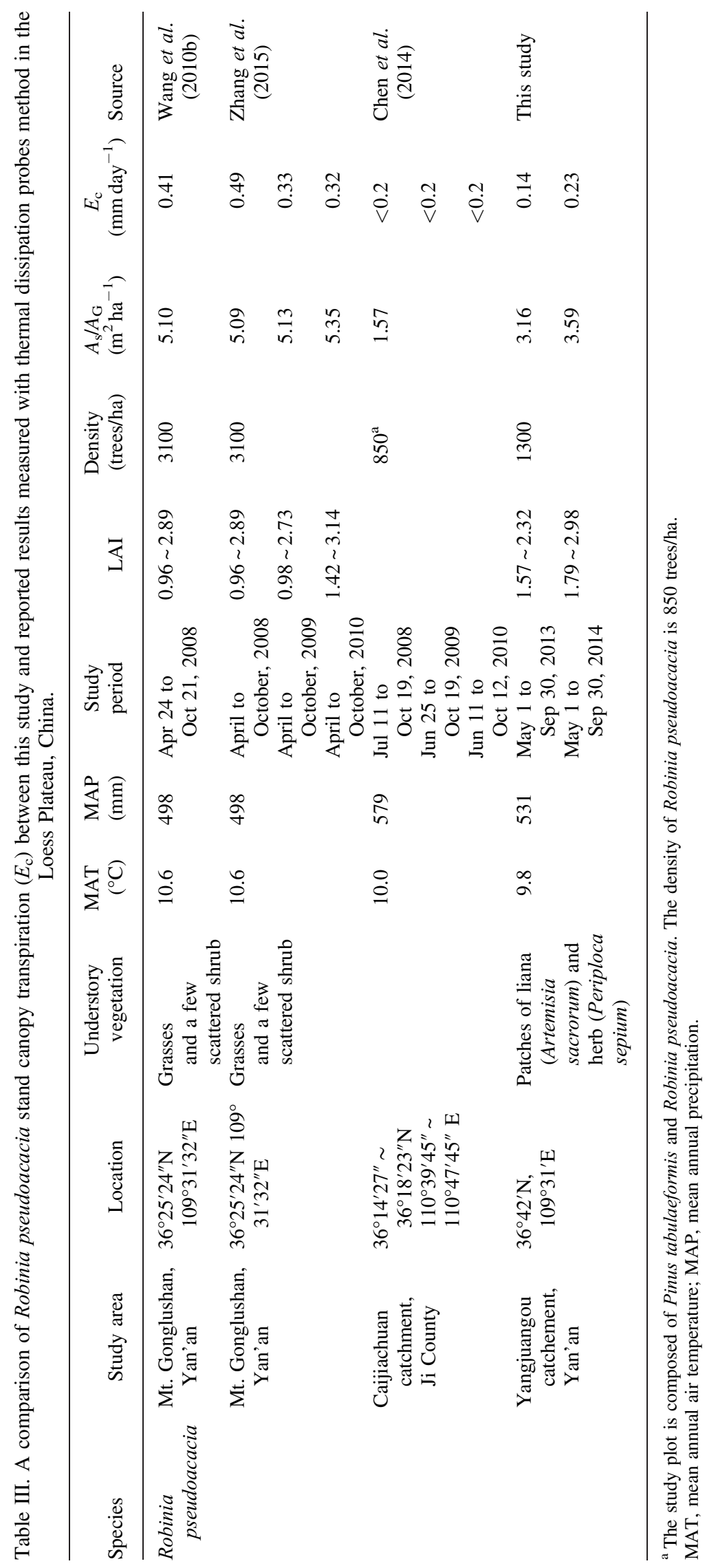


Table IV. Monthly mean and peak stand sap flux density $\left(J_{\mathrm{s}}, \mathrm{kg} \mathrm{m}^{-2} \mathrm{day}^{-1}\right)$ during May to September in 2013 and 2014.

\begin{tabular}{|c|c|c|c|}
\hline Year & Month & Mean $J_{\mathrm{s}}\left(\mathrm{kg} \mathrm{m}^{-2} \mathrm{day}^{-1}\right)$ & Peak $J_{\mathrm{s}}\left(\mathrm{kg} \mathrm{m}^{-2} \mathrm{day}^{-1}\right)$ \\
\hline \multirow[t]{5}{*}{2013} & May & $541.5 \pm 154.1$ & 728.0 \\
\hline & Jun & $529.92 \pm 128.4$ & 688.0 \\
\hline & Jul & $397.8 \pm 141.0$ & 652.2 \\
\hline & Aug & $407.8 \pm 141.0$ & 591.4 \\
\hline & Sep & $277.4 \pm 99.9$ & 464.7 \\
\hline \multirow[t]{5}{*}{2014} & May & $665.9 \pm 140.7$ & 978.9 \\
\hline & Jun & $823.9 \pm 160.0$ & 1273.9 \\
\hline & Jul & $801.3 \pm 194.1$ & 1166.2 \\
\hline & Aug & $507.7 \pm 146.0$ & 732.1 \\
\hline & Sep & $402.6 \pm 160.9$ & 735.0 \\
\hline
\end{tabular}

\section{Factors affecting on $E_{\mathrm{c}}$}

It is well known that at a given stand $E_{\mathrm{c}}$ is mainly controlled not only by climatic variables but also by the soil water available in the root zone (Granier et al., 2000a, 2000b; Ewers et al., 2002; Kumagai et al., 2008; Ghimire et al., 2014; Chang et al., 2014b). Previous studies focused on relationships between $E_{\mathrm{c}}$ and the independent environmental factor, such as $R_{\mathrm{S}}$ and VPD, and threshold responses wer+e observed in individual tree and canopy transpiration to $R_{\mathrm{s}}$ and VPD (Granier et al., 1996; Kumagai et al., 2008; Ghimire et al., 2014; Chang et al., 2014b). Ewers et al. (2002) developed an exponential saturation to describe the threshold relationship between $E_{\mathrm{c}}$ and environmental factors, which was widely used to examine the regulation of environmental factors on $E_{\mathrm{c}}$ (Ewers et al., 2007; Du et al., 2011; Zhang et al., 2015). For example, the model with VPD and $R_{\mathrm{S}}$ can explain $77 \sim 78 \%$ and $50 \sim 57 \%$ variations in daily stand transpiration rate in Japanese cedar forests, respectively (Kumagai et al., 2008). Regulations of VPD on daily tree transpiration of different species in northern Wisconsin were moderately verified by the model (Ewers et al., 2007). Ghimire et al. (2014) showed that $E_{\mathrm{c}}$ exhibited a threshold relationship with VPD and $R_{\mathrm{S}}$ in a natural broad-leaved forest and planted coniferous forest in the Lesser Himalaya of Central Nepal, with threshold values of $0.4 \mathrm{kPa}$ for VPD and $200 \mathrm{~W} \mathrm{~m}^{-2}$ for $R_{\mathrm{s}}$. In this study, daily $E_{\mathrm{c}}$ increased sharply with increasing VPD and a VPD threshold was showed, with approximately 1.5 in 2013 and $1.0 \mathrm{kPa}$ in 2014 . Similarly, $E_{\mathrm{c}}$ reasonably increased with increasing $R_{\mathrm{s}}$ and levelled off at a threshold value of around $250 \mathrm{~W} \mathrm{~m}^{-2}$ in both growing seasons. Ewers' model including $R_{\mathrm{s}}$ or VPD can explain the variability of daily $E_{\mathrm{c}} . R_{\mathrm{S}}$ could explain $60 \%$ and $45 \%$ variability of $E_{\mathrm{c}}$ in 2013 and 2014, respectively, compared with VPD explaining $58 \%$ and $40 \%$ variability of $E_{\mathrm{c}}$. However, a clear relationship between daily $E_{\mathrm{c}}$ and SWC was not found (Figure 4c). Some studies showed that plants have the ability to tap water from deeper soil layers in semi-arid environment (Li et al., 2002; David et al., 2007; Xu et al., 2007). A likely reason for this is that black locust taps water from deeper soil layers, especially when top soil moisture is exhausted (Kumagai et al., 2008; Brito et al., 2015).

At the monthly scale, the stepwise regression analysis implied that the variations in LAI determined the magnitudes and patterns of $E_{\mathrm{c}}$ in this study. Some other studies also concluded that LAI was a major proxy to estimate ET or $E_{\mathrm{c}}$ at a monthly scale. Zhang et al. (2015) found that LAI was one of the major factors that tightly correlated with monthly $E_{\mathrm{c}}$ in the black locust plantation in Mt. Gonglushan, $30 \mathrm{~km}$ from our study site. Similarly, a study on oak forest by Xie et al. (2014) suggested LAI explained $78 \%$ of the monthly total ET measured by the eddy covariance method over a 7-year study period. The global syntheses by Sun et al. (2011) and Fang et al. (2015) also indicate that LAI is a major predictor of ET at the ecosystem level.

The relationship between $E_{\mathrm{c}}$ and SWC was analysed by separating the SWC regime as the pre-rainy season and rainy season. Contrary to June of the pre-rainy season, SWC significantly increased in July of the rainy season because of more $P$ replenishing (Figure 3 ). However, $E_{\mathrm{c}}$ in July have not increased but declined compared with that in June $(4.0 \mathrm{~mm}$ to $5.0 \mathrm{~mm}$ in 2013 and $8.9 \mathrm{~mm}$ to $9.0 \mathrm{~mm}$ in 2014). In the rainy season in 2014, SWC dramatically improved and exhibited an increased trend from July to September, while $E_{\mathrm{c}}$ declined from 8.9 to $4.3 \mathrm{~mm} \mathrm{month}^{-1}$ (Table II). The transpiration rate in the pre-rainy season was higher than that in the rainy season, and monthly $E_{\mathrm{c}}$ peaked in June when the drought was exacerbated in both growing seasons (Figure 3). Additionally, although SWC and $P$ in the whole growing season of 2013 were higher than in 2014, $E_{\mathrm{c}}$ in 2013 was lower in 2014 because of lower LAI in 2013 (Figure 5). Previous findings showed that SWC at the beginning of the growing season exerts a crucial influence on stand development (e.g. LAI and DBH increment) and consequently affected gas exchange of the ecosystem (Kwon et al., 2008; Noormets et al., 2008; Dong et al., 2011). It is noted that SWC in May and June 2013 was significantly lower than that in same period of 2014 . 
LAI in 2013 was lower than that in 2014. It is implied that variation in LAI in the two growing seasons was possibly related to SWC at the beginning of growing season, resulting in variations in annual $E_{\mathrm{c}}$ in this study. Therefore, our 2-year study indicated that SWC mediated annual $E_{\mathrm{c}}$ by modifying LAI.

\section{Implication for regional water resource and restoration management}

In this study, $E_{\mathrm{c}}$ accounted for a small proportion in stand water balance during the two growing seasons (only $3.4 \%$ of $P$ in 2013 and $8.0 \%$ of in 2014). Although we did not measure all the water budget components, a closer examination of the fluxes offered some insights of the relative magnitude of total water use by the plantations. For example, $E_{\mathrm{i}}$ and $E_{\mathrm{s}}$ possibly accounted for a larger proportion of ET in the black locust plantation according to the formula 8 . A study showed that $E_{\mathrm{s}}$ was nearly twofolds to threefolds of $E_{\mathrm{c}}$ both in natural and irrigated black locust plantations in this region (Hou et al., 2003). With SWC increased, more water would evaporate from the soil under similar climatic conditions (Zhang et al., 2007). It is implied that the magnitude of $E_{\mathrm{s}}$ was larger than that of $E_{\mathrm{c}}$. Moreover, $E_{\mathrm{i}}$ during the growing season estimated by the Gash analytical model was $65.7 \mathrm{~mm}$ in 2013 and $50.9 \mathrm{~mm}$ in 2014. Although the values are approximately estimated, it is suggested that $E_{\mathrm{i}}$ is higher than $E_{\mathrm{c}}$ in the black locust plantation. In June 2013, assuming no surface runoff occurred because of the low $P$ and dry soil in this period, ET was estimated to be $32.5 \mathrm{~mm}$ according to formula 7 . Therefore, $E_{\mathrm{c}}$ accounted for $15.4 \%$ of monthly ET in June 2013. For the wet periods in 2013, $Q$ should be considered on the hillslopes to construct the water balance of the black locust plantation. For example, $Q$ probably increased as a consequence of extreme rainfall events in July 2013. Relatively, a large amount of $Q$ was observed in nearby experimental runoff plots covered with grass, shrub and orchard located in the Yangjuangou catchment.

Previous studies showed that soil desiccation in deep soil layers was developed and soil water scarcity was aggravated in vegetation rehabilitation areas, especially in black locust plantations (Wang et al., 2010a; Wang et al., 2011). It was generally believed that one of the possible reasons for soil desiccation was that artificial vegetation (i.e. black locust) consumed more water than native vegetation in semi-arid Loess Plateau (Wang et al., 2004b; Chen et al., 2008). Soil water excessive depletion resulted in potential negative impact on water resources and decreased tree growth (Wang et al., 2004a, 2004b) Therefore, the sustainability of black locust plantations in this region was widely studied in recent years (Shan et al., 2003; Wang et al., 2004a; Jin et al., 2011). Our finding indicated that the transpiration of the black locust plantation was remarkably lower than previously believed. We argue that the black locust plantation might have adapted to the local soil water condition in the semi-arid environment on the Loess Plateau.

$E_{\mathrm{c}}$ values estimated by sap flow could be moderately underestimated because of potential error in estimation in $E_{\mathrm{c}}$ due to radial variation in $F_{\mathrm{d}}$ across the sapwood area in this study. Nonetheless, $E_{\mathrm{c}}$ values estimated by sapflow could approximated represent general magnitude of $E_{\mathrm{c}}$. A future study should take radial variation in $F_{\mathrm{d}}$ into consideration to derive the accurate $E_{\mathrm{c}}$ estimates.

We found considerable variability of water use at daily, seasonal and inter-annual scales in this 2-year study. It appears that soil water conditions at the beginning of the growing season had a great influence on tree development, leaf area and water use in the next few months. Future studies should further examine the linkages of non-growing season soil water conditions with tree growth in both previous and current years.

\section{CONCLUSION}

Black locust was widely planted for revegetation in the semiarid Loess Plateau. In contrary to the wide perception that black locust plantations use a large amount of soil water, we found that $E_{\mathrm{c}}$ of the plantation was low and was not a major component of the stand water balance even though possible limitation of $E_{\mathrm{c}}$ estimates because of radial variations in $F_{\mathrm{d}}$ in sapwood area. A further study should investigate the full water budget of the plantation to offer useful information for managing the forest covers in the study region.

Our study also found that responses of daily $E_{\mathrm{c}}$ to $R_{\mathrm{s}}$ and VPD were well explained by an exponential saturation model. Whereas, LAI was the dominate factor controlling $E_{\mathrm{c}}$ at monthly and annual scales. Accurate LAI data (e.g. from monitoring and remote sensing products) are necessary to estimate accurate monthly $E_{\mathrm{c}}$ in this region. Variation in soil water at the beginning of growing season possibly induced variation in annual LAI, resulting in variation in annual $E_{\mathrm{c}}$. The potential influences of soil water availability in pregrowing or initial growing season on $E_{\mathrm{c}}$ and vegetation development in the following growing season should be further studied in the future.

\section{ACKNOWLEDGEMENTS}

This study is financially supported by the National Natural Science Foundation of China (Nos. 41390462 and 41201182). We sincerely express thanks to Cong Wang, Jianbo Liu, Chen Dong, Chuan Yuan, Ji Zhou and Dr. Linhai Zhu for their considerable assistances in the field work. We sincerely thanked two anonymous reviewers for their constructive comments and helpful suggestions. 


\section{REFERENCES}

Allen RG, Pereira LS, Raes D, Smith M. 1998. Crop evapotranspirationguidelines for computing crop water requirements-FAO irrigation and drainage paper 56, FAO, Rome, Italy.

Bernier PY, Bartlett P, Black TA, Barr A, Kljun N, McCaughey JH. 2006. Drought constraints on transpiration and canopy conductance in mature aspen and jack pine stands. Agricultural and Forest Meteorology 140: 64-78. DOI:10.1016/j.agrformet.2006.03.019.

Brito P, Lorenzo JR, Gonzalez-Rodriguez AM, Morales D, Wieser G, Jimenez MS. 2015. Canopy transpiration of a semi arid Pinus canariensis forest at a treeline ecotone in two hydrologically contrasting years. Agricultural and Forest Meteorology 201: 120-127. DOI:10.1016/j.agrformet.2014.11.008.

Campbell GS, Norman JM. 1998. An Introduction to Environmental Biophysics. Springer-Verlag: New York.

Chang XX, Zhao WZ, He ZB. 2014a. Radial pattern of sap flow and response to microclimate and soil moisture in Qinghai spruce (Picea crassifolia) in the upper Heihe River Basin of arid northwestern China. Agricultural and Forest Meteorology 187: 14-21. DOI:10.1016/j. agrformet.2013.11.004.

Chang XX, Zhao WZ, Liu H, Wei X, Liu B, He ZB. 2014b. Qinghai spruce (Picea crassifolia) forest transpiration and canopy conductance in the upper Heihe River Basin of arid northwestern China. Agricultural and Forest Meteorology 198: 209-220. DOI:10.1016/j. agrformet.2014.08.015.

Chen HS, Shao MA, Li YY. 2008. Soil desiccation in the Loess Plateau of China. Geoderma 143: 91-100. DOI:10.1016/j.geoderma.2007.10.013.

Chen LX, Zhang ZQ, Zeppel M, Liu CF, Guo JT, Zhu JZ, Zhang XP, Zhang JJ, Zha TG. 2014. Response of transpiration to rain pulses for two tree species in a semiarid plantation. International Journal of Biometeorology 58: 1569-1581. DOI:10.1007/s00484-013-0761-9.

Clearwater MJ, Meinzer FC, Andrade JL, Goldstein G, Holbrook NM. 1999. Potential errors in measurement of nonuniform sap flow using heat dissipation probes. Tree Physiology 19: 681-687. DOI:10.1093/ treephys/19.10.681.

Cohen Y, Cohen S, Cantuarias-Aviles T, Schiller G. 2007. Variations in the radial gradient of sap velocity in trunks of forest and fruit trees. Plant and Soil 305: 49-59. DOI:10.1007/s11104-007-9351-0.

David TS, Henriques MO, Kurz-Besson C, Nunes J, Valente F, Vaz M, Pereira JS, Siegwolf R, Chaves MM, Gazarini LC, David JS. 2007. Water-use strategies in two co-occurring Mediterranean evergreen oaks: surviving the summer drought. Tree Physiology 27: 793-803. DOI:10.1093/treephys/27.6.793.

del Campo AD, Fernandes TJG, Molina AJ. 2014. Hydrology-oriented (adaptive) silviculture in a semiarid pine plantation: How much can be modified the water cycle through forest management? European Journal of Forest Research 133: 879-894. DOI:10.1007/s10342-014-0805-7.

Delzon S, Sartore M, Granier A, Loustau D. 2004. Radial profiles of sap flow with increasing tree size in maritime pine. Tree Physiology 24: 1285-1293.

Denmead OT, Dunin FX, Wong SC, Greenwood EAN. 1993. Measuring water use efficiency of Eucalypt trees with chambers and micrometeorological techniques. Journal of Hydrology 150: 649-664. DOI:10.1016/0022-1694(93)90130-2.

Dong G, Guo JX, Chen JQ, Sun G, Gao S, Hu LJ, Wang YL. 2011. Effects of spring drought on carbon sequestration, evapotranspiration and water use efficiency in the Songnen Meadow Steppe in northeast China. Ecohydrology 4: 211-224. DOI:10.1002/eco.200.

Du S, Wang YL, Kume T, Zhang JG, Otsuki K, Yamanaka N, Liu GB. 2011. Sapflow characteristics and climatic responses in three forest species in the semiarid Loess Plateau region of China. Agricultural and Forest Meteorology 151: 1-10. DOI:10.1016/j.agrformet.2010.08.011.

Ewers BE, Mackay DS, Gower ST, Ahl DE, Burrows SN, Samanta SS 2002. Tree species effects on stand transpiration in northern Wisconsin. Water Resources Research 38: 8_1-8_11. DOI:10.1029/ 2001wr000830.

Ewers BE, Mackay DS, Samanta S. 2007. Interannual consistency in canopy stomatal conductance control of leaf water potential across seven tree species. Tree Physiology 27: 11-24. DOI:10.1093/treephys/27.1.11.

Fang Y, Sun G, Caldwell P, McNulty SG, Noormets A, Domec JC, King J, Zhang Z, Zhang X, Lin G. 2015. Monthly land cover-specific evapotranspiration models derived from global eddy flux measurements and remote sensing data. Ecohydrology: accepted article. DOI: 10.1002/eco.1629

Feng XM, Fu BJ, Lu N, Zeng Y, Wu BF. 2013. How ecological restoration alters ecosystem services: an analysis of carbon sequestration in China's Loess Plateau. Scientific Reports 3: 2846. DOI:10.1038/srep02846.

Ford CR, Goranson CE, Mitchell RJ, Will RE, Teskey RO. 2004. Diurnal and seasonal variability in the radial distribution of sap flow: predicting total stem flow in Pinus taeda trees. Tree Physiology 24: 941-950. DOI:10.1093/treephys/24.9.951.

Gash JHC. 1979. An analytical model of rainfall interception by forests. Royal Meteorological Society, Quarterly Journal 105: 43-55.

Ghimire CP, Lubczynski MW, Bruijnzeel LA, Chayarro-Rincon D. 2014. Transpiration and canopy conductance of two contrasting forest types in the Lesser Himalaya of Central Nepal. Agricultural and Forest Meteorology 197: 76-90. DOI:10.1016/j.agrformet.2014.05.012.

Granier A. 1987. Evaluation of transpiration in a Douglas-fir stand by means of sap flow measurements. Tree Physiology 3: 309-320. DOI:10.1093/treephys/3.4.309.

Granier A, Biron P, Lemoine D. 2000a. Water balance, transpiration and canopy conductance in two beech stands. Agricultural and Forest Meteorology 100: 291-308. DOI:10.1016/S0168-1923(99)00151-3.

Granier A, Huc R, Barigah ST. 1996. Transpiration of natural rain forest and its dependence on climatic factors. Agricultural and Forest Meteorology 78: 19-29. DOI:10.1016/0168-1923(95)02252-X.

Granier A, Loustau D, Breda N. 2000b. A generic model of forest canopy conductance dependent on climate, soil water availability and leaf area index. Annals of Forest Science 57: 755-765. DOI:10.1051/forest:2000158.

Hou ZH, He KN, Zhang XQ. 2003. Study on water requirement of black locust Forest in semi-arid region on Loess Plateau of Northwest Shanxi. Journal of Soil and Water Conservation 17: 180-183.

Jarvis PG, Mcnaughton KG. 1986. Stomatal control of transpiration - scaling up from leaf to region. Advances in Ecological Research 15: 1-49.

Jiao F, Wen Z-M, An S-S, Yuan Z. 2013. Successional changes in soil stoichiometry after land abandonment in Loess Plateau, China. Ecological Engineering 58: 249-254. DOI:10.1016/j. ecoleng.2013.06.036.

Jin TT, Fu BJ, Liu GH, Wang Z. 2011. Hydrologic feasibility of artificial forestation in the semi-arid Loess Plateau of China. Hydrology and Earth System Sciences 15: 2519-2530. DOI:10.5194/hess-15-2519-2011.

Katul G, Manzoni S, Palmroth S, Oren R. 2010. A stomatal optimization theory to describe the effects of atmospheric $\mathrm{CO} 2$ on leaf photosynthesis and transpiration. Annals of Botany 105: 431-42. DOI:10.1093/ aob/mcp292.

Kelley G, O'Grady AP, Hutley LB, Eamus D. 2007. A comparison of tree water use in two contiguous vegetation communities of the seasonally dry tropics of northern Australia: the importance of site water budget to tree hydraulics. Australian Journal of Botany 55: 700-708. DOI: $10.1071 / \mathrm{bt} 07021$

Kumagai T, Tateishi M, Miyazawa Y, Kobayashi M, Yoshifuji N, Komatsu H, Shimizu T. 2014. Estimation of annual forest evapotranspiration from a coniferous plantation watershed in Japan (1): Water use components in Japanese cedar stands. Journal of Hydrology 508: 66-76. DOI:10.1016/j.jhydrol.2013.10.047.

Kumagai T, Tateishi M, Shimizu T, Otsuki K. 2008. Transpiration and canopy conductance at two slope positions in a Japanese cedar forest watershed. Agricultural and Forest Meteorology 148: 1444-1455. DOI:10.1016/j.agrformet.2008.04.010.

Kumagai T, Aoki S, Shimizu T, Otsuki K. 2007. Sap flow estimates of stand transpiration at two slope positions in a Japanese cedar forest watershed. Tree Physiology 27: 161-168.

Kume T, Otsuki K, Du S, Yamanaka N, Wang YL, Liu GB. 2012. Spatial variation in sap flow velocity in semiarid region trees: its impact on stand-scale transpiration estimates. Hydrological Processes 26: 1161-1168.

Kume T, Takizawa H, Yoshifuji N, Tanaka K, Tantasirin C, Tanaka N, Suzuki M. 2007. Impact of soil drought on sap flow and water status of evergreen trees in a tropical monsoon forest in northern Thailand. Forest Ecology and Management 238: 220-230. DOI:10.1016/j. foreco.2006.10.019.

Kupper P, Sellin A, Tenhunen J, Schmidt M, Rahi M. 2006. Effects of branch position on water relations and gas exchange of European larch 
trees in an alpine community. Trees-Structure and Function 20: 265-272. DOI:10.1007/s00468-005-0033-3.

Kwon H, Pendall E, Ewers BE, Cleary M, Naithani K. 2008. Spring drought regulates summer net ecosystem $\mathrm{CO}_{2}$ exchange in a sagebrushsteppe ecosystem. Agricultural and Forest Meteorology 148: 381-391. DOI:10.1016/j.agrformet.2007.09.010.

Li Y, Fuchs M, Cohen S, Cohen Y, Wallach R. 2002. Water uptake profile response of corn to soil moisture depletion. Plant, Cell and Environment 25: 491-500. DOI:10.1046/j.1365-3040.2002.00825.x.

Limousin JM, Rambal S, Ourcival JM, Rocheteau A, Joffre R, RodriguezCortina R. 2009. Long-term transpiration change with rainfall decline in a Mediterranean Quercus ilex forest. Global Change Biology 15: 2163-2175. DOI:10.1111/j.1365-2486.2009.01852.x.

Lu P, Müller WJ, Chacko EK. 2000. Spatial variations in xylem sap flux density in the trunk of orchard-grown, mature mango trees under changing soil water conditions. Tree Physiology 20: 683-692.

Lu P, Urban L, Zhao P. 2004. Granier's thermal dissipation probe (TDP) method for measuring sap flow in trees: Theory and practice. Acta Botanica Sinica 46: 631-646.

Lundblad M, Lindroth A. 2002. Stand transpiration and sapflow density in relation to weather, soil moisture and stand characteristics. Basic and Applied Ecology 3: 229-243. DOI:10.1078/1439-1791-00099.

MacKay SL, Arain MA, Khomik M, Brodeur JJ, Schumacher J, Hartmann H, Peichl M. 2012. The impact of induced drought on transpiration and growth in a temperate pine plantation forest. Hydrological Processes 26: 1779-1791. DOI:10.1002/hyp.9315.

Mantovani D, Veste M, Freese D. 2014. Black locust (Robinia pseudoacacia L.) ecophysiological and morphological adaptations to drought and their consequence on biomass production and water-use efficiency. New Zealand Journal of Forestry Science 44: 29. DOI:10.1186/s40490-014-0029-0.

Manzoni S, Vico G, Katul G, Fay PA, Polley W, Palmroth S, Porporato A. 2011. Optimizing stomatal conductance for maximum carbon gain under water stress: a meta-analysis across plant functional types and climates. Functional Ecology 25: 456-467. DOI:10.1111/j.13652435.2010.01822.x.

Nadezhdina N, Cermak J, Ceulemans R. 2002. Radial patterns of sap flow in woody stems of dominant and understory species: scaling errors associated with positioning of sensors. Tree Physiology 22: 907-918. DOI:10.1093/treephys/22.13.907.

Noormets A, McNulty SG, DeForest JL, Sun G, Li Q, Chen J. 2008. Drought during canopy development has lasting effect on annual carbon balance in a deciduous temperate forest. New Phytologist 179: 818-28. DOI:10.1111/j.1469-8137.2008.02501.x.

Olbrich BW. 1991. The verification of the heat pulse velocity technique for estimating sap flow in Eucalyptus grandis. Canadian Journal of Forest Research 21: 836-841. DOI:10.1139/X91-117.

Oren R, Pataki DE. 2001. Transpiration in response to variation in microclimate and soil moisture in southeastern deciduous forests. Oecologia 127: 549-559. DOI:10.1007/s004420000622.

Oren R, Zimmermann R, Terborgh J. 1996. Transpiration in upper Amazonia floodplain and upland forests in response to droughtbreaking rains. Ecology 77: 968-973. DOI:10.2307/2265517.

Schlesinger WH, Jasechko S. 2014. Transpiration in the global water cycle. Agricultural and Forest Meteorology 189: 115-117. DOI:10.1016/j.agrformet.2014.01.011.

Shan CJ, Liang ZS, Hao WF. 2003. Review on growth of locust and soil water in Loess Plateau. Acta Bot Boreal Occident Sin 23: 1314-1346.

Shangguan ZP. 2007. Soil desiccation occurrence and its impact on forest vegetation in the Loess Plateau of China. International Journal of Sustainable Development and World Ecology 14: 299-306. DOI:10.1080/13504500709469730.

Small EE, McConnell JR. 2008. Comparison of soil moisture and meteorological controls on pine and spruce transpiration. Ecohydrology 1: 205-214. DOI:10.1002/eco.25.

Sun G, Alstad K, Chen JQ, Chen SP, Ford CR, Lin GH, Liu CF, Lu N, McNulty SG, Miao HX, Noormets A, Vose JM, Wilske B, Zeppel M, Zhang Y, Zhang ZQ. 2011. A general predictive model for estimating monthly ecosystem evapotranspiration. Ecohydrology 4: 245-255. DOI:10.1002/eco.194.
Sun G, Zhou GY, Zhang ZQ, Wei XH, McNulty SG, Vose JM. 2006. Potential water yield reduction due to forestation across China. Journal of Hydrology 328: 548-558. DOI:10.1016/j.jhydrol. 2005.12.013.

Sun XC, Onda Y, Kato H, Otsuki K, Gomi T. 2014. Partitioning of the total evapotranspiration in a Japanese cypress plantation during the growing season. Ecohydrology 7: 1042-1053. DOI:10.1002/eco.1428.

Vertessy RA, Benyon RG, Osullivan SK, Gribben PR. 1995. Relationships between stem diameter, sapwood area, leaf-area and transpiration in a young mountain ash forest. Tree Physiology 15: 559-567. DOI:10.1093/treephys/15.9.559.

Wang L, Shao MA, Li YY. 2004a. Study on relationship between growth of artificial Robinia pseudoacacia plantation and soil desiccation in the Loess Plateau of northern Shannxi Province. Scientia Silvae Sinicae 40: 84-91.

Wang L, Shao MA, Wang QJ, Jia ZK, Li J. 2004b. Review of research on soil desiccation in the Loess Plateau. Transactions of the CSAE 20: 27-31.

Wang L, Zhang QF, Shao MA, Wang QJ. 2013. Rainfall interception in a Robinia pseudoacacia forest stand: estimates using Gash's analytical model. Journal of Hydrologic Engineering 18: 474-479. DOI:10.1061/ (asce)he.1943-5584.0000640.

Wang S, Fu BJ, Gao GY, Yao XL, Zhou J. 2012. Soil moisture and evapotranspiration of different land cover types in the Loess Plateau, China. Hydrology and Earth System Sciences 16: 2883-2892. DOI:10.5194/hess-16-2883-2012.

Wang Y, Ma S, Liu Z. 2010a. Large-scale spatial variability of dried soil layers and related factors across the entire Loess Plateau of China. Geoderma 159: 99-108. DOI:10.1016/j.geoderma.2010.07.001.

Wang YL, Liu GB, Kume T, Otsuki K, Yamanaka N, Du S. 2010b. Estimating water use of a black locust plantation by the thermal dissipation probe method in the semiarid region of Loess Plateau, China. Journal of Forest Research 15: 241-251. DOI:10.1007/s10310-010-0184-y.

Wang YQ, Shao MA, Zhu YJ, Liu ZP. 2011. Impacts of land use and plant characteristics on dried soil layers in different climatic regions on the Loess Plateau of China. Agricultural and Forest Meteorology 151: 437-448. DOI:10.1016/j.agrformet.2010.11.016.

Wei X, Sun G. 2009. Watershed ecosytem process and management. Higher Education Press: Beijing.

Wullschleger SD, Meinzer FC, Vertessy RA. 1998. A review of wholeplant water use studies in trees. Tree Physiology 18: 499-512. DOI:10.1093/treephys/18.8-9.499.

Xie J, Sun G, Chu H-S, Liu J, McNulty SG, Noormets A, John R, Ouyang Z, Zha T, Li H, Guan W, Chen J. 2014. Long-term variability in the water budget and its controls in an oak-dominated temperate forest. Hydrological Processes 28: 6054-6066. DOI:10.1002/hyp.10079.

$\mathrm{Xu} \mathrm{H}, \mathrm{Li}$ Y, Xu GQ, Zou T. 2007. Ecophysiological response and morphological adjustment of two Central Asian desert shrubs towards variation in summer precipitation. Plant, Cell and Environment 30: 399-409. DOI:10.1111/j.1365-3040.2006.001626.x.

Zeppel MJB, Yunusa IAM, Eamus D. 2006. Daily, seasonal and annual patterns of transpiration from a stand of remnant vegetation dominated by a coniferous Callitris species and a broad-leaved Eucalyptus species. Physiologia Plantarum 127: 413-422. DOI:10.1111/j.13993054.2006.00674.x.

Zhang JG, Guan JH, Shi WY, Yamanaka N, Du S. 2015. Interannual variation in stand transpiration estimated by sap flow measurement in a semi-arid black locust plantation, Loess Plateau, China. Ecohydrology 8: 137-147. DOI:10.1002/eco.1495.

Zhang W, Liu W, Xue Q, Chen J, Han X. 2013. Evaluation of the AquaCrop model for simulating yield response of winter wheat to water on the southern Loess Plateau of China. Water Science and Technology 68: 821-8. DOI:10.2166/wst.2013.305.

Zhang WQ, He KN, Zhou Y, Deng JT, Gan XH. 2007. Study on soil evaporation of the Robinia pseudoacacia forest land in semi-arid region of the Loess Plateau. Research of Soil and Water Conservation 14: 367-370.

Zhao WZ, Liu B. 2010. The response of sap flow in shrubs to rainfall pulses in the desert region of China. Agricultural and Forest Meteorology 150: 1297-1306. DOI:10.1016/j.agrformet.2010.05.012. 